\title{
Mimosa splendida Barneby (Mimosoideae, Leguminosae) rediscovered in Central Brazil: preliminary studies for conservation of a rare species
}

\author{
MARCELO F. SIMON ${ }^{1,2,3}$ and MARINA F. AMARAL ${ }^{1}$
}

(received: October 24, 2001; accepted: January 2, 2003)

\begin{abstract}
Mimosa splendida Barneby (Mimosoideae, Leguminosae) rediscovered in Central Brazil: preliminary studies for conservation of a rare species). The poorly known Mimosa splendida Barneby has been rediscovered in the Chapada dos Veadeiros, Brazil, 105 years after its single record in 1895. Data on its habitat description, demography, reproductive parameters, and geographic range are presented. Preliminary results suggest that the rarity of $M$. splendida in herbarium collections is associated with a narrow geographic range, and a specialized habitat preference on rocky slopes.
\end{abstract}

Key words - Cerrado, "Chapada dos Veadeiros”, demography, endemism, life history

RESUMO - (Mimosa splendida Barneby (Mimosoideae, Leguminosae) reencontrada no Brasil Central: estudos preliminares para conservação de uma espécie rara). Mimosa splendida Barneby, uma espécie pouco conhecida é redescoberta na Chapada dos Veadeiros, Brasil, 105 anos após seu único registro em 1895. São apresentados a descrição do habitat, demografia, parâmetros reprodutivos e distribuição geográfica dessa espécie. Resultados preliminares sugerem que a escassez de $M$. splendida em herbários está associada a uma distribuição geográfica restrita e à ocorrência em encostas pedregosas.

Palavras-chave - Cerrado, Chapada dos Veadeiros, ciclo de vida, demografia, endemismo

\section{Introduction}

The "Chapada dos Veadeiros", a highlands complex located in the State of Goiás, Central Brazil (ca. $14^{\circ} \mathrm{S}$ and $47^{\circ} \mathrm{W}$ ), is notable for its rich and endemic flora, especially in Leguminosae, Eriocaulaceae, Lythraceae, Compositae, Gramineae, Melastomataceae, and Velloziaceae (Munhoz \& Proença 1998). The region is one of the most important centers of diversity and endemism for the genus Mimosa, with more than 40 species and approximately 20 endemics (Simon \& Proença 2000).

The altitude in this region ranges from 550 to $1,700 \mathrm{~m}$ and sandstone lithosol is the predominant soil. Climate is Aw based on the Köppen (1936) system, with mean annual rainfall of about $1,500 \mathrm{~mm}$ and a dry season from May to September. The mean annual temperature is $20{ }^{\circ} \mathrm{C}$. The area includes several kinds of phytophysiognomies, such as grassland ("campo limpo"), wet grassland ("vereda"), gallery forest, savanna ("cerrado"), savanna woodland ("cerradão"), and upland rocky grassland ("campo rupestre"). This latter kind occurs in the highlands and is strongly associated with

1. Universidade de Brasília, Departamento de Ecologia, 70919-970 Brasília, DF, Brazil.

2. Present address: Embrapa, Secretaria de Administração Estratégica, PqEB, W3 Norte (final), 70770-901 Brasília, DF, Brazil.

3. Corresponding author: marcelo.simon@embrapa.br endemism (Giulietti \& Pirani 1988, Alves \& Kolbek 1994, Harley 1995, Simon \& Proença 2000). In a preliminary checklist, Munhoz \& Proença (1998) recorded 1,310 species for the "Chapada dos Veadeiros", but this number is certainly underestimated. The "Chapada dos Veadeiros" is a relatively well-collected site in Central Brazil, with more than 3,600 specimens collected between 1965 and 1972 by H.S. Irwin and W.R. Anderson, and many others collections in more recent botanical surveys. The total number of exsiccatae so far collected in this region might easily be 5,000.

Glaziou collected Mimosa splendida in 1895, and published a list of his collections (Glaziou 1906) in which the specimen Glaziou 21088 was cited as M. pyrrhopila Harms ex Glaziou (nomen nudum). The location of the collection was given as Rio dos Couros, a small river in the south of the Chapada dos Veadeiros. Later, Barneby (1991) described this species based only upon Glaziou's collection, and cited M. splendida as a poorly-known species that botanists were urged to rediscover before its habitat was destroyed. In a recent survey of Mimosa in Central Brazil (Simon \& Proença 2000), over 3,000 recent specimens of Mimosa from the most representative Central Brazilian herbaria were examined, but no collections of M. splendida were found. In this paper we report the discovery of a population of $M$. splendida in the Chapada dos Veadeiros, exactly 105 years after the original Glaziou collection. 


\section{Material and methods}

We studied the demography of $M$. splendida at the end of the reproductive period (June 2001) at Fazenda São Bento ( $14^{\circ} 10^{\prime} \mathrm{S}$ and $47^{\circ} 35^{\prime} \mathrm{W}, 1,200 \mathrm{~m}$ altitude), which belongs to the Rio dos Couros basin, and is probably close to its first collection. The population was sampled with ten randomly placed $2 \times 50 \mathrm{~m}$ plots. In each plot we counted all individuals, measured their height and stem circumference at $10 \mathrm{~cm}$ (or at the plant base in small individuals), and verified if the plant was a reproductive individual, present or past, based on the presence of reproductive structures. We also collected mature pods that were still closed, and analyzed them in the laboratory to assess seed set and seed predation.

Voucher specimens of M. splendida (Simon \& Amaral 316 and 430) were deposited at Universidade de Brasília
Herbarium (UB), with duplicates sent to CEN, HUEFS, HUFG, and SPF (acronyms according to Holmgren et al. 1990).

\section{Results and Discussion}

Mimosa splendida, a candelabriform treelet, is illustrated in figure 1. Remarkable features are the crowded leaves on the top of branches, the stem densely covered by persistent stipules, a very slender setose indumentum clothing leafstalks, peduncules and stipules, and the valvate pod typical of series Pachycarpae. Mimosa splendida grows on rocky slopes with well-drained and shallow lithosols (sandstone derived), in "campo rupestre" or "cerrado rupestre"

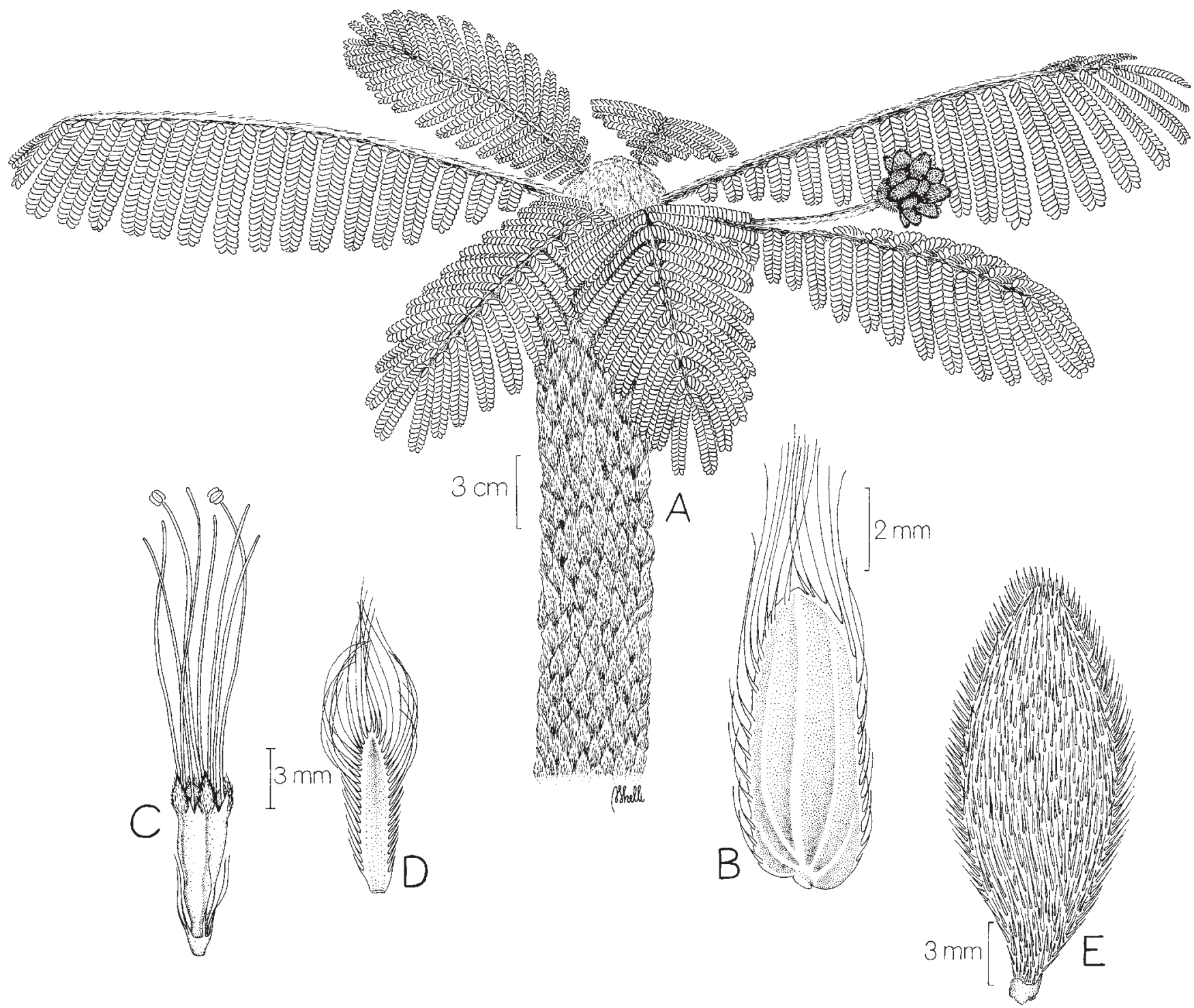

Figure 1. Mimosa splendida Barneby. A. Reproductive branch, showing mature fruits. B. Leaflet, dorsal view. C. Flower. D. Floral bract, ventral view. E. Fruit. (Simon \& Amaral 430). 
(sensu Ribeiro \& Walter 1998), and is sympatric with Mimosa claussenii Benth., M. ulei Taub., M. venatorum Barneby, and other sparse trees and shrubs such as Lychnophora ericoides Mart., Vochysia thyrsoidea Pohl, V. pumila A. St.-Hil., Qualea parviflora Mart., Sclerolobium paniculatum Vog., and Palicourea rigida Kunth, with a ground layer dominated by Gramineae and Cyperaceae.

Among 102 sampled individuals, 75.5\% were non reproductive, with the majority of these in the low height and intermediate circumference categories (figures 2A, B). This suggests that seedlings first allocate resources in lateral growth until they reach approximately $12 \mathrm{~cm}$ tall, and subsequently they increase in height, being able to attain more than $3 \mathrm{~m}$ (figure 3). Population density was $10.2 \pm 3.5$ ind.100 m-2 (mean \pm standard deviation, $\mathrm{n}=10$ ). Plants become reproductive when attain approximately $12 \mathrm{~cm}$ in circumference and $30 \mathrm{~cm}$ in height (figure 3 ). The mean number of fruits produced per inflorescence was
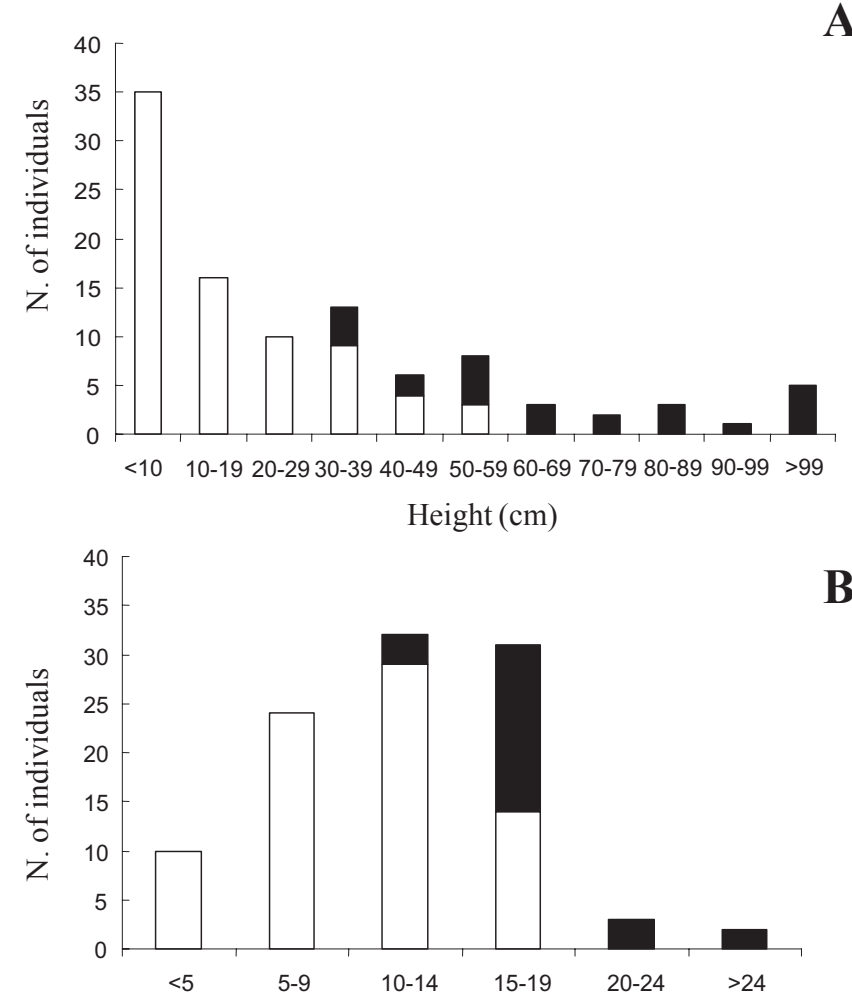

Stem circumference $(\mathrm{cm})$

Figure 2. Number of individuals of Mimosa splendida sampled in ten $100 \mathrm{~m}^{2}$ plots according to height (A), and stem circumference categories (B), at Chapada dos Veadeiros. ( $\square=$ non-reproductive plants; $\square=$ reproductive plants).

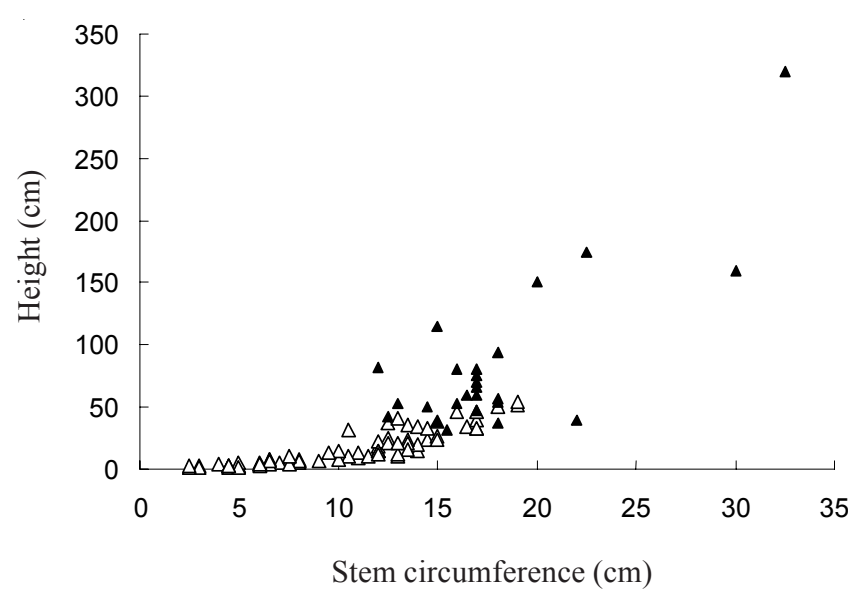

Figure 3. Relationship between stem circumference and height in 102 individuals of Mimosa splendida sampled at Chapada dos Veadeiros. ( $\triangle=$ non-reproductive plants; $\boldsymbol{\Delta}=$ reproductive plants).

$10.4 \pm 7.2(\mathrm{n}=46)$. Pods produce 1 to 4 seeds $(1.9 \pm$ $0.9, \mathrm{n}=145)$, but mature pods which lack seeds also occur. We examined seeds of 145 mature pods collected from more than 20 individuals, and found that $63.6 \%$ of seeds were intact, $25.5 \%$ were aborted or undeveloped, and $10.9 \%$ were predated or attacked by fungus. The main pre-dispersal seed predators were larvae of Bruchidae beetles, which also attack other Mimosa species in Central Brazil (Simon 2001). We found no evidence of vegetative reproduction in exhumed seedlings, which indicates that seed production is probably the only mechanism of population increase. These demographic and reproductive features are also found in other species of Mimosa (ser. Pachycarpae) that occur in the Central Brazilian highlands (Simon 2001). A parallel population structure was found for M. claussenii Benth., a common species with similar growth habit in which young individuals also first invest in lateral growth and thereafter in height (Simon 2001). This growth strategy may be related to avoidance of fire damage, because cerrado plants with thicker stems have higher survival rates after fire (Sato \& Miranda 1996). The percentage of intact seeds recorded in M. splendida was near to those found in the endemics M. decorticans Barneby, M. setosissima Taub., and $M$. heringeri Barneby, which range from 66 to $80 \%$ (Simon 2001).

The geographic range of $M$. splendida is still unknown but in this preliminary survey we recorded its occurrence in three patches, all of them on mountain slopes with the same habitat as described above. The two closest patches were located on the Fazenda São 
Bento and are $2.2 \mathrm{~km}$ from each other, the third patch is about 5.8 and $3.5 \mathrm{~km}$ from the other two.

Although the region where M. splendida grows has been reasonably well collected, this species has been recorded for a second time only 105 years after its first collection by Glaziou in 1895 . This suggests that the species has a very narrow geographic range, and despite its conspicuous habit and relatively high local density, it has been rarely encountered.

Preliminary demographic results from Fazenda São Bento shows that M. splendida has a "reverse J" shape height distribution (figure 2A), which is characteristic of stable populations (Hutchings 1986). Field observations indicate a strong habitat specialization on rocky mountain slopes, an occasional environment that is patchily distributed over the landscape, which reduces the availability of suitable habitats for this species. Combined high specialization and low habitat availability contribute to enhance the vulnerability of this rare species despite its high local density. Thus it may be classified as "vulnerable" according IUCN threatened categories (Davis et al. 1986). Additional studies concerning population viability and the determination of total geographic range are necessary to support conservation measures for this notable species. The regional flora is locally protected within the National Park of the "Chapada dos Veadeiros" (236,570 ha), but M. splendida has not yet been found there, which reinforces the importance of protecting areas surrounding the Park.

Acknowledgements - We are indebted to the manager of Fazenda São Bento for permission to work on his property, and to C. Proença for her helpful comments on this manuscript.

\section{References}

ALVES, R.J.V. \& KOLBEK, J. 1994. Plant species endemism in savanna vegetation on table mountains (camporupestre) in Brazil. Vegetatio 113:125-139.

BARNEBY, R.C. 1991. Sensitivae censitae: a description of the genus Mimosa Linnaeus (Mimosaceae) in the New World. Memoirs of the New York Botanical Garden $65: 1-835$.
DAVIS, S.D., DROOP, S.J.M., GREGERSON, P., HENSON, L., LEON, C.J., VILLA-LOBOS, J.L., SYNGE, H. \& ZANTOVSKA, J. 1986. Plants in danger. What do we know? International Union for Conservation of Nature and Natural Resources, Cambridge.

GIUliETTI, A.M. \& PIRANI, J.R. 1988. Patterns of geographic distribution of some plant species from the Espinhaço range, Minas Gerais and Bahia, Brazil. In Proceedings of a Workshop on Neotropical Biodiversity Distribution Patterns (W.R. Heyer \& P.E. Vanzolini, eds.). Academia Brasileira de Ciências, Rio de Janeiro, p.39-69.

GLAZIOU, A.F.M. 1906. Mimosa. In Liste des plantes du Brésil central. Bulletin de la Société Botanique de France 53(Mém.3b):177-186.

HARLEY, R.M. 1995. Introduction. In Flora of the Pico das Almas, Chapada Diamantina, Brazil (B.L. Stannard, ed.). Royal Botanic Gardens, Kew, p.1-37.

HOLMGREN, P., HOLMGREN, N. \& BARNETT, L. 1990. Index Herbariorum. Part I: The Herbaria of the World. International Association for Plant Taxonomy and New York Botanical Garden, New York.

HUTCHINGS, M.J. 1986. The structure of plant populations. In Plant Ecology (M.J. Crowley, ed.). Blackwell Scientific, Oxford, p.97-136.

KÖPPEN, W. 1936. Das geographische system der klimate. Handbuch der klimatologie. Gebrüder Borntrager, Berlin.

MUNHOZ, C.\& PROENÇA, C. 1998. Composição florística do Município de Alto Paraíso de Goiás na Chapada dos Veadeiros. Boletim do Herbário Ezequias Paulo Heringer 3:102-150.

RIBEIRO, J. \& WALTER, B. 1998. Fitofisionomias do bioma Cerrado. In Cerrado: ambiente e flora (S. Sano \& S. Almeida, eds.). Embrapa-CPAC, Planaltina, p.89-166.

SATO, M. \& MIRANDA, H. 1996. Mortalidade de plantas lenhosas do cerrado sensu stricto submetidas a diferentes regimes de queima. In Anais do Simpósio Impacto de Queimadas sobre os Ecossistemas e Mudanças Globais. $3^{\text {o }}$ Congresso de Ecologia do Brasil (H. Miranda, C. Saito \& B. Dias, eds.). Universidade de Brasília, Brasília, p.102-111.

SIMON, M.F. 2001. Ecologia de quatro espécies de Mimosa (Mimosaceae) no Brasil Central: uma comparação entre espécies raras e comuns. Dissertação de mestrado, Universidade de Brasília, Brasília.

SIMON, M.F. \& PROENÇA, C. 2000. Phytogeographic patterns of Mimosa (Mimosoideae, Leguminosae) in the Cerrado biome of Brazil: an indicator genus of high-altitude centers of endemism? Biological Conservation 96:279-296. 